\title{
Evaluasi Perilaku Penggunaan Obat Sebelum Pasien Terdiagnosa Penyakit Ginjal Kronis Di Rsud Soesilo Kabupaten Tegal Dan Rsud Kardinah Kota Tegal Periode Januari - Agustus 2016 \\ Khusny Kamal ${ }^{* 1}$, Yusi Anggriani ${ }^{2}$, Hesty Utami Ramadaniati ${ }^{3}$ \\ ${ }^{123}$ Fakultas Farmasi Universitas Pancasila, Jakarta e-mail: ${ }^{1}$ khusnykamal@gmail.com
}

\section{Article Info}

Article history:

Submission Mei 2020

Accepted Juni 2020

Publish Juli 2020
Ucapan Terima kasih diberikan pembimbing tesis fakultas farmasi yang telah membantu kelancaran penelitian ini

\begin{abstract}
Abstrak
Jumlah penderita Chronic Kidney Disease (CKD) terus meningkat dan dianggap sebagai salah satu masalah kesehatan yang dapat berkembang menjadi epidemi. Peningkatan pemakaian produk over the counter (OTC), penggunaan obat tradisional yang tercampur bahan kimia obat, penggunaan obat keras secara bebas membawa keprihatinan dan kekhawatiran akan kualitas, efektivitas, keamanan dari produk yang dipakai. Penelitian ini bertujuan untuk melihat distribusi penderita, perilaku penggunaan obat sebelum terdiagnosis PGK di RSUD Soeselo dengan RSUD Kardinah. Metode yang digunakan dalam penelitian ini adalah cross sectional dengan pemberian kuesioner secara prospektif pada pasien yang masuk kedalam kriteria inklusi. Sampel yang digunakan adalah penderita ginjal kronis yang menjalani perawatan di RSUD Soeselo sebanyak 56 responden dan 138 responden di RSUD Kardinah pada periode januari 2016 - agustus 2016. Data dianilisis secara statistik menggunakan uji chi square untuk melihat proporsi distribusi PGK dan perilaku penggunaan obat pasien di RSUD Soeselo dengan RSUD Kardinah. Berdasarkan hasil penelitian, pada karakteristik demografi didapat jenis kelamin laki-laki, usia >50 tahun, jenis pekerjaan dengan aktivitas fisik sedang proporsi yang tinggi di RSUD Kardinah sedangkan distribusi tingkat pendidikan sedang proporsi terbanyak di RSUD Soeselo.. Pada perilaku penggunaan obat anti nyeri paling banyak digunakan adalah obat pereda sakit(42,6\%), dimana terdapat perbedaan perilaku yang signifikan di RSUD Soeselo dengan RSUD Kardinah pada perilaku penggunaan jamu kemasan di racik dirumah dan jamu gendong dimana proporsi penggunaan di RSUD Kardinah jauh lebih tinggi daripada di RSUD Soesilo dimana nilai p-value ( $p<0,05)$ sedangkan pada penggunaan obat atau suplemen kesehatan yang paling banyak digunakan adalah jamu kemasan diracik dirumah $(22,6 \%)$ serta tidak ditemukan perbedaan secara signifikan $(p>0,05)$ untuk perilaku penggunaan suplemen kesehatan untuk menjaga stamina dan kesehatan di kedua rumah sakit.
\end{abstract}

Kata kunci- Penyakit ginjal kronis, profil pengobatan, perilaku penggunaan obat, RSUD Soeselo dan RSUD Kardinah 
by giving prospective questionnaires to patients who fall into the inclusion criteria. The sample used was chronic kidney patients undergoing treatment at Soeselo Regional Hospital as many as 56 respondents and 138 respondents at the Kardinah Regional Hospital in the period January 2016 - August 2016. Data were analyzed statistically using the chi square test to see the proportion of CKD distribution and behavior of drug use of patients in the Regional Hospital Soeselo with Kardinah Regional Hospital. Based on the results of the study, the demographic characteristics obtained male sex, age> 50 years, the type of occupation with moderate physical activity is a high proportion in Kardinah Regional Hospital while the distribution of education level is the highest proportion in Soeselo Regional Hospital. the most widely used is pain reliever (42.6\%), where there are significant behavioral differences in Soeselo Regional Hospital with Kardinah Regional Hospital on the behavior of using herbal medicine in racik at home and in the holding of herbal medicine where the proportion of usage in Kardinah Regional Hospital is much higher than in Soesilo Regional Hospital $p$-value $(p<0.05)$ while the most widely used drugs or health supplements are herbal medicine packaging at home (22.6\%) and no significant differences were found ( $p>0.05$ ) for supplement use behavior health to maintain stamina and health in both hospitals.

Keyword - Chronic kidney disease, treatment profile, drug use behavior, Soeselo Regional Hospital and Kardinah Regional Hospital

\footnotetext{
Alamat korespondensi:

Prodi DIII Farmasi Politeknik Harapan Bersama Tegal

Gedung A Lt.3. Kampus 1

Jl. Mataram No.09 Kota Tegal, Kodepos 52122

Telp. (0283) 352000

E-mail: parapemikir_poltek@yahoo.com
}

p-ISSN: 2089-5313

e-ISSN: 2549-5062 


\section{A. Pendahuluan}

Penyakit gagal ginjal merupakan penyakit yang menganggu fungsi organ ginjal, dimana fungsi organ ginjal menurun hingga akhirnya tidak lagi mampu bekerja sama sekali ${ }^{[1]}$. Di berbagai negara, peningkatan jumlah penderita penyakit ginjal kronis dapat menjadi salah satu masalah kesehatan yang bisa berkembang menjadi epidemi ${ }^{[2]}$. Dalam beberapa tahun terakhir meningkatnya pertumbuhan dari pemakaian produk over the counter (OTC) di negara-negara maju baik berupa makanan kesehatan, nutraseutikal, dan produk obat dari tanaman atau sumber alam lainnya membawa keprihatinan dan kekhawatiran akan kualitas, efektivitas, keamanan dari produk yang dipakai ${ }^{[3]}$.

Sebagian obat diekskresikan melalui ginjal, bila ginjal mengalami gangguan fungsi maka pemberian obat tentunya harus disesuaikan ${ }^{[4]}$. Hasil penelitian menunjukkan bahwa 20-25\% dari kasus gagal ginjal yang dirawat disebabkan oleh obat atau zat kimia, dan penelitian lain mencatat bahwa pada tahun 1976 - 1980, dari sebanyak 28 penderita gagal ginjal yang dirawat, empat penderita $(14,3 \%)$ disebabkan karena nefrotoksik ${ }^{[5]}$. Di beberapa daerah di Amerika Serikat, sebanyak 7 sampai 10 persen dari kasus penyakit ginjal stadium akhir telah dikaitkan dengan penyalahgunaan analgesik dan di negara lain, jumlah 2 persen menjadi 30 persen dari kasus penyakit ginjal tahap akhir telah dikaitkan dengan penyalahgunaan analgetika ${ }^{[6]}$.

Perkembangan penyakit gagal ginjal ini sangat berdampak pada produktivitas seseorang, perkembangan penyakit ini perlu dipantau secara terpadu agar jumlah penderita mengalami penurunan. Berdasarkan latar belakang di atas yang peneliti melakukan penelitian tentang perilaku penggunaan obat sebelum pasien terdiagnosa penyakit ginjal kronis di RSUD Soeselo dengan RSUD Kardinah yang saat ini masih menjadi penyakit yang mengganggu produktivitas dan menjadi salah satu faktor mortalitas.

\section{B. Metode}

\section{Subyek Penelitian}

Subyek penelitian adalah pasien yang terdiagnosa penyakit ginjal kronis yang menjalani perawatan di RSUD Soeselo Kabupaten Tegal dan RSUD Kardinah Kota Tegal periode Januari 2016 - Agustus 2016. Kriteria inklusi pada penelitian ini adalah pasien yang terdiagnosa penyakit ginjal kronik yang menjalani perawatan di RSUD Soeselo Kabupaten Tegal dan RSUD Kardinah Kota Tegal dan bersedia menandatangani informed consent. Sedangkan, kriteria eksklusi pada penelitian ini adalah pasien yang penderita ginjal akut atau pasien dengan riwayat penyakit ginjal bawaan atau transplantasi ginjal dan pasien yang tidak mau terlibat dalam penelitian ini.

\section{Rancangan Penelitian.}

Penelitian ini merupakan penelitian deskriptif analitik dengan menggunakan desain penelitian cross sectional dengan pengambilan data secara prospektif. Analisis data digunakan untuk mengetahui profil karakteristik penderita penyakit ginjal kronis yang menjalani perawatan di RSUD Soeselo dan RSUD Kardinah periode Januari 2016Agustus 2016, proporsi penderita berdasarkan riwayat penyakit penyerta dan profil pengobatan penyakit hipertensi, diabetes mellitius serta anemia. Untuk melihat distribusi proporsi perilaku penggunaan obat sebelum terdiagnosa penyakit ginjal kronis menggunakan kuesioner yang diadopsi dari kuesioner PROM (pusat riset obat dan makanan) tentang studi kasus ginjal kronis dimana yang digunakan adalah tentang penggunaan obat antinyeri untuk mengatasi gejala atau penyakit dan penggunaan suplemen obat untuk menjaga kesehatan dan stamina.

\section{Hasil Dan Pembahasan}

Dari 194 pasien yang terdiagnosa penyakit ginjal kronis dimana penyebaran penderita tersebut, sebanyak 56 pasien penyakit ginjal kronis menjalani pengobatan di RSUD Soeselo Kabupaten Tegal dan sebanyak 138 pasien penyakit ginjal kronis yang menjalani pengobatan di RSUD Kardinah Kota Tegal.

\section{Karakteristik Demografi}

Pada penelitian ini, gambaran distribusi demografi didapatkan hasil bahwa untuk distribusi penderita ginjal kronis berdasarkan jenis kelamin didominasi jenis kelamin lakilaki $(64,9 \%)$, distribusi berdasarkan umur didominasi umur $51-60$ tahun (34\%), distribusi berdasarkan tingkat pendidikan di dominasi dengan pendidikan sedang $(60,3 \%)$, 
distribusi berdasarkan tingkat pekerjaan didominasi dengan tingkat pekerjaan menggunakan fisik sedang $(45,9 \%)$. Riwayat penyakit yang di derita oleh pasien penderita ginjal kronis pada penelitian ini didominasi pasien dengan riwayat hipertensi $(51,5 \%)$ dan diabetes mellitius $(15 \%)$.

Tabel 1. Distribusi Demografi Dan Riwayat Penyakit Penderita Pada Pasien Ginjal Kronis Di RSUD Soeselo Dan RSUD Kardinah

\begin{tabular}{|c|c|c|c|c|c|c|}
\hline & \multicolumn{2}{|c|}{ RSUD Soeselo } & \multicolumn{2}{|c|}{ RSUD Kardinah } & \multicolumn{2}{|c|}{ Total } \\
\hline Jenis Kelamin & $\mathrm{n}$ & $\%$ & $\mathrm{n}$ & $\%$ & $\mathrm{n}$ & $\%$ \\
\hline Laki - Laki & 34 & 60,7 & 92 & 66,7 & 126 & 64,9 \\
\hline Perempuan & 22 & 39,3 & 46 & 33,3 & 68 & 35,1 \\
\hline \multicolumn{7}{|l|}{ Umur } \\
\hline Range & \multirow{2}{*}{\multicolumn{2}{|c|}{$21-77$}} & \multicolumn{2}{|c|}{$24-67$} & \multicolumn{2}{|c|}{$21-77$} \\
\hline Mean & & & \multicolumn{2}{|c|}{50,30} & \multicolumn{2}{|c|}{50,45} \\
\hline Median & \multicolumn{2}{|c|}{$\begin{array}{l}50,04 \\
53,50\end{array}$} & \multirow{2}{*}{\multicolumn{2}{|c|}{53,50}} & \multicolumn{2}{|c|}{53,00} \\
\hline Standar Deviasi & \multicolumn{2}{|c|}{13,9} & 10,9 & & \multicolumn{2}{|c|}{11,8} \\
\hline 20th - 30th & \multicolumn{2}{|c|}{\begin{tabular}{l|l}
13,9 \\
\multicolumn{1}{|c|}{10.7}
\end{tabular}} & 9 & 6,5 & 15 & 7,7 \\
\hline 31 th -40 th & 10 & 17,9 & 17 & 12,3 & 27 & 13,9 \\
\hline 41th -50 th & 9 & 16,1 & 32 & 23,2 & 41 & 21,2 \\
\hline 51 th -60 th & 14 & 25 & 52 & 37,7 & 66 & 34 \\
\hline$>60$ th & 17 & 30,4 & 28 & 20,3 & 45 & 23,2 \\
\hline \multicolumn{7}{|l|}{ Tingkat pendidikan } \\
\hline Pendidikan rendah & 12 & 21,4 & 41 & 29,7 & 53 & 27,3 \\
\hline Pendidikan sedang & 40 & 71,4 & 77 & 55,8 & 117 & 60,3 \\
\hline Pendidikan tinggi & 4 & 7,2 & 20 & 14,5 & 24 & 12,4 \\
\hline \multicolumn{7}{|l|}{ Tingkat Pekerjaan } \\
\hline Berbasis Pengetahuan & 12 & 21,4 & 42 & 30,5 & 54 & 27,8 \\
\hline Berbasis Fisik & 40 & 71,4 & 87 & 63 & 127 & 65,5 \\
\hline Bukan Keduanya & 4 & 7,2 & 9 & 6,5 & 13 & 6,7 \\
\hline \multicolumn{7}{|l|}{ Riwayat Penyakit } \\
\hline Hipertensi & 26 & 46,4 & 73 & 52,9 & 99 & 51 \\
\hline Diabetes & 1 & 1,8 & 5 & 3,6 & 6 & 3,1 \\
\hline Hipertensi + Diabetes & 3 & 5,4 & 30 & 21,7 & 33 & 17 \\
\hline Bukan Keduanya & 26 & 46,4 & 30 & 21,7 & 56 & 28,9 \\
\hline
\end{tabular}

Dari tabel 1 didapatkan bahwa proporsi pada pasien berjenis kelamin laki-laki baik di RSUD Soeselo (60,7\%) maupun RSUD Kardinah $(66,7 \%)$ paling mendominasi hal ini bisa kita katakan bahwa karakteristik penderita ginjal kronik di RSUD Soeselo dan RSUD Kardinah berdasarkan jenis kelamin proporsinya tidak jauh berbeda.

Data dari The United States Renal Data System (USRDS) pada tahun 2006 yang menyatakan bahwa risiko terjadinya penyakit ginjal kronis meningkat pada populasi berjenis kelamin laki - laki. Rata-rata penurunan GFR secara signifikan lebih cepat pada laki-laki muda dibandingkan wanita muda dan sering sekali perbedaan jumlah penderita ini dikaitkan dengan adanya faktor hormonal, dimana pada pada laki - laki hormon androgen dapat mempercepat kerusakan ginjal sedangkan wanita hormon estrogen cenderung bersifat renoprotektif ${ }^{[7,8]}$.

Pada distribusi umur didapatkan hasil penderita penyakit ginjal kronis di tiap rumah sakit sebanding dan memiliki tren semakin bertambahnya umur maka semakin banyak jumlah penderita ginjal kronis dimana kelompok umur 51th - 60th sebesar 34\% dan kelompok umur lebih

dari 60 tahun $23,2 \%$ dimana rata-rata penderita ginjal kronis terjad pada umur $>50$ tahun. Salah satu faktor meningkatnya penyakit ginjal kronis adalah bertambahnya umur, karena umur dapat mempengaruhi Gromerular filtration rate (GFR). Dimana ketika fungsi GFR terganggu atau menurun 
dapat diartikan terjadinya penurunan fungsi ginjal serta progresivitas ke arah penyakit ginjal kronik

Tingkat pendidikan yang sedang dan rendah memiliki jumlah proporsi yang terdiagnosa penyakit ginjal kronis lebih besar dari pada tingkat pendidikan tinggi. Latar belakang tingkat pendidikan cenderung berpengaruh terhadap pemilihan obat, pengobatan sendiri dengan memperhatikan aspek keamanan, ketepatan, dan kerasionalan obat, dimana semakin tinggi tingkat pendidikan seseorang maka semakin rasional dan berhati - hati dalam memilih obat.

Secara keseluruhan dapat dikatakan bahwa proporsi jenis pekerjaan yang paling banyak pada penderita ginjal kronis yaitu pada jenis pekerjaan yang menggunakan fisik sedang serta banyak. Pada umumnya pendidikan sangat erat hubungannya dengan pekerjaan, dan dengan jenis pekerjaan mempengaruhi gaya hidup seseorang, baik pola makan, olah raga, dan pekerjaan yang dapat meningkatkan stres seseorang.

Berdasarkan beberapa literatur menyebutkan bahwa hipertensi dan diabetes mellitus merupakan faktor inisiasi. Penyakit hipertensi dan penyakit ginjal sering dikaitkan sebagai suatu lingkaran setan dimana penyakit hipertensi bisa menyebabkan penyakit ginjal dan sebaliknya. Pada keadaan hipertensi dimana tekanan darah semakin meningkat dan sulit terkontrol mengakibatkan pembuluh darah didalam ginjal semakin tertekan sehingga membuat pembuluh darah menjadi rusak dan menyebabkan fungsi ginjal menurun hingga mengalami kegagalan ginjal ${ }^{[9,10]}$. Pada pasien diabetes tingginya kadar gula darah akan membuat struktur ginjal berubah sehingga terjadi gangguan fungsi ginjal dan merusak pembuluh darah halus di ginjal sehingga menimbulkan kerusakan glomerulus yang berfungsi sebagai penyaring darah ${ }^{[10]}$.

\section{Profil Pengobatan}

Penggunaan terapi antihipertensi pada penelitian ini sangat bervariasi, mulai dari pemilihan terapi tunggal sampai dengan kombinasi obat antihipertensi. Terapi obat antihipertensi pada penderita penyakit ginjal kronis bertujuan untuk mengendalikan tekanan darah yang terjadi karena perubahan hemodinamika dan dapat menjadi progresivitas penyakit jika tidak dikendalikan
[7].

Profil penggunaan obat hipertensi paling banyak pada penelitian ini adalah penggunaan golongan diuretik sebesar 35\%, CCBs sebanyak 29,6\%, AIIRA sebanyak 22,2\%, sentral $\alpha$ agonis $7,2 \%$, ace inhibitor sebesar $3,4 \%$ dan golongan $\beta$ blocker sebesar 2,5\%. Terapi antihipertensi yang digunakan adalah terapi tunggal dan kombinasi. Dimana pada terapi tunggal antihipertensi yang digunakan pada pasien ginjal kronis di RSUD Soeselo dengan RSUD Kardinah proporsinya sebanding yang di dominasi oleh antihihipertensi golongan diuretik. Sedangkan pada terapi kombinasi didominasi oleh kelompok kombinasi 2 obat antihipertensi sebesar $38,6 \%$. Terdapat perbedaan pada penggunaan kombinasi 2 antihipertensi, yaitu pada pasien yang menjalani perawatan di RSUD Soeselo didominasi CCBs+diuretik sedangkan di RSUD Kardinah AIIRA+diuretik.

Pemakaian obat antihipertensi ini bertujuan untuk memperlambat pemburukan kerusakan nefron dan memperkecil risiko terjadinya penyakit kardiovaskuler. Beberapa obat antihipertensi menurut beberapa studi terbukti dapat memperlambat proses pemburukan fungsi ginjal yaitu obat penghambat enzim converting angiotensin di mana mekanisme kerjanya sebagai antihipertensi dan penghambat proteinuria ${ }^{[9]}$.

Penggunaan obat antidiabetik pada penelitian ini sangat beragam diantaranya yaitu golongan sulfonilurea menempati proporsi tertinggi sebesar $48,8 \%$, kemudian golongan biguanid sebesar $27,9 \%$, insulin sebesar $18,6 \%$ dan alfa glikosidase sebesar 4,7\%. Di negara Amerika Serikat nefropati diabetik merupakan penyebab utama gagal ginjal [11], sedangkan di negara indonesia prevalensi nefropati diabetik hanya $8,3 \%$ dari semua kejadian gagal ginjal kronik. Salah satu akibat dari komplikasi kronik diabetes melitus adalah terjadinya nefropati diabetik yang akan meningkat menjadi ESRD. Nefropati diabetik ini gejala awal ditandai adanya protein dalam urin dengan adanya protein dalam urin yang terjadi sangat hebat sehingga penderita mengalami kekurangan protein dalam darah yang mengakibatkan timbulnya sindroma nefotik dan jika berlangsung terus menerus maka akan terjadi penyakit gagal ginjal terminal ${ }^{[12]}$. 


\section{Perilaku Penggunaan Obat Antiyeri}

Perilaku penggunaan obat pereda sakit sebelum pasien terdiagnosa penyakit ginjal kronis untuk mengatasi gejala atau penyakit, yang menjalani pengobatan di kedua rumah sakit masih dominan sekitar $65 \%$ dari pada yang tidak menggunakan obat pereda sakit.

Tabel 2. Perilaku Penggunaan Obat Nyeri Untuk Mengatasi Gejala Atau Penyakit

\begin{tabular}{|c|c|c|c|c|c|}
\hline \multirow{2}{*}{\multicolumn{2}{|c|}{ Jenis Obat }} & \multicolumn{2}{|c|}{ Pasien PGK } & \multirow[b]{2}{*}{ Total } & \multirow[b]{2}{*}{ p-value } \\
\hline & & \multirow{2}{*}{$\begin{array}{c}\text { RSUD } \\
\text { Soeselo } \\
36(64,3)\end{array}$} & \multirow{2}{*}{$\begin{array}{c}\text { RSUD } \\
\text { Kardinah } \\
91(65,9)\end{array}$} & & \\
\hline \multirow[t]{2}{*}{ Pereda Sakit } & Ya & & & $127(65,5)$ & \multirow{2}{*}{0,958} \\
\hline & Tidak & $20(35,7)$ & $47(34,1)$ & $67(34,5)$ & \\
\hline \multirow[t]{2}{*}{ Antiinflamasi } & $\mathrm{Ya}$ & $3(5,4)$ & $1(0,7)$ & $4(2,1)$ & \multirow{2}{*}{0,073} \\
\hline & Tidak & $53(94,6)$ & $137(99,3)$ & $190(97,9)$ & \\
\hline \multirow[t]{2}{*}{ Racikan dari Apotek } & $\mathrm{Ya}$ & $1(1,8)$ & $2(1,4)$ & $3(1,5)$ & \multirow{2}{*}{1,000} \\
\hline & Tidak & $55(98,2)$ & $136(98,6)$ & $191(98,5)$ & \\
\hline \multirow[t]{2}{*}{ Paten dibeli sendiri } & $\mathrm{Ya}$ & $32(57,1)$ & $64(46,4)$ & $96(49,5)$ & \multirow{2}{*}{0,230} \\
\hline & Tidak & $24(42,9)$ & $74(53,6)$ & $98(50,5)$ & \\
\hline \multirow[t]{2}{*}{ Obat China } & $\mathrm{Ya}$ & $15(26,8)$ & $33(23,9)$ & $48(24,7)$ & \multirow{2}{*}{0,813} \\
\hline & Tidak & $41(73,2)$ & $105(76,1)$ & $146(75,3)$ & \\
\hline \multirow{2}{*}{$\begin{array}{l}\text { Jamu Kemasan diracik } \\
\text { di rumah }\end{array}$} & $\mathrm{Ya}$ & $6(10,7)$ & $4(2,9)$ & $10(5,2)$ & \multirow{2}{*}{0,035} \\
\hline & Tidak & $50(89,3)$ & $134(97,1)$ & $184(94,8)$ & \\
\hline \multirow[t]{2}{*}{ Jamu Gendong } & $\mathrm{Ya}$ & $6(10,7)$ & $2(1,4)$ & $8(4,1)$ & \multirow{2}{*}{0,008} \\
\hline & Tidak & $50(89,3)$ & $136(98,6)$ & $186(95,9)$ & \\
\hline
\end{tabular}

Perilaku penggunaan obat antinyeri proporsi yang paling banyak di tempati dengan obat pereda sakit yaitu sebesar $42,6 \%$, selanjutnya $32,2 \%$ obat paten yang dibeli sendiri, dan sebesar $16,1 \%$ adalah obat china. Penggunaan obat pereda sakit pada pasien ginjal kronis di RSUD Soeselo didominasi dengan pekerjaan berbasis fisik yaitu sebesar $77,8 \%$ ternyata proporsinya jauh lebih besar dari pada penderita ginjal kronis di RSUD Kardinah yaitu sebesar 59,3\%. Untuk perilaku penggunaan obat paten yang dibeli sendiri ternyata keduanya memiliki proporsi penggunaan yang sama yaitu sebesar $68,8 \%$ digunakan oleh pasien ginjal kronis dengan jenis pekerjaan berbasis fisik. Hal yang berbeda pada penggunaan obat china dimana proporsi yang tinggi pada pasien di RSUD Kardinah sebesar $75,8 \%$ sedangkan $73,3 \%$ pada pasien di RSUD Soeselo yang kesemuanya dengan pekerjaan berbasis fisik.

Beberapa bukti epidemiologis menunjukkan bahwa terdapat hubungan antara penggunaan analgetika dan antiinflamasi non steroid berlebihan dengan kejadian kerusakan ginjal atau nefropati. Penggunaan NSAIDs terhadap ginjal sering dikaitkan dengan toksisitasnya, dikarenakan terjadi efek penghambatan terhadap prostaglandin. Walaupun efeknya relatif kecil namun apabila digunakan dalam jangka waktu yang lama dan dosis yang tinggi dapat menimbulkan efek pada ginjal ${ }^{[11,13]}$.

Beberapa studi kasus menemukan sediaan obat herbal yang cara pembuatan tidak mengikuti standar, sediaan yang dipalsukan ataupun bahkan penambahan obat kimia misalnya phenylbutazone yang dosisnya tidak sesuai bisa berakibat pada gangguan fungsi ginjal bahkan bisa sampai terjadi kerusakan ginjal, hal ini bisa terjadi karena di berbagai negara produk herbal belum diatur sebagai obat. Banyak produk herbal yang merugikan dikarenakan yaitu tanaman herbal terkontaminasi dengan obat - obatan, hormon, atau logam berat ${ }^{[11,14]}$. 
Perilaku Penggunaan suplemen obat

Tabel 3. Perilaku Penggunaan Suplemen Untuk Menjaga Kesehatan Dan Stamina

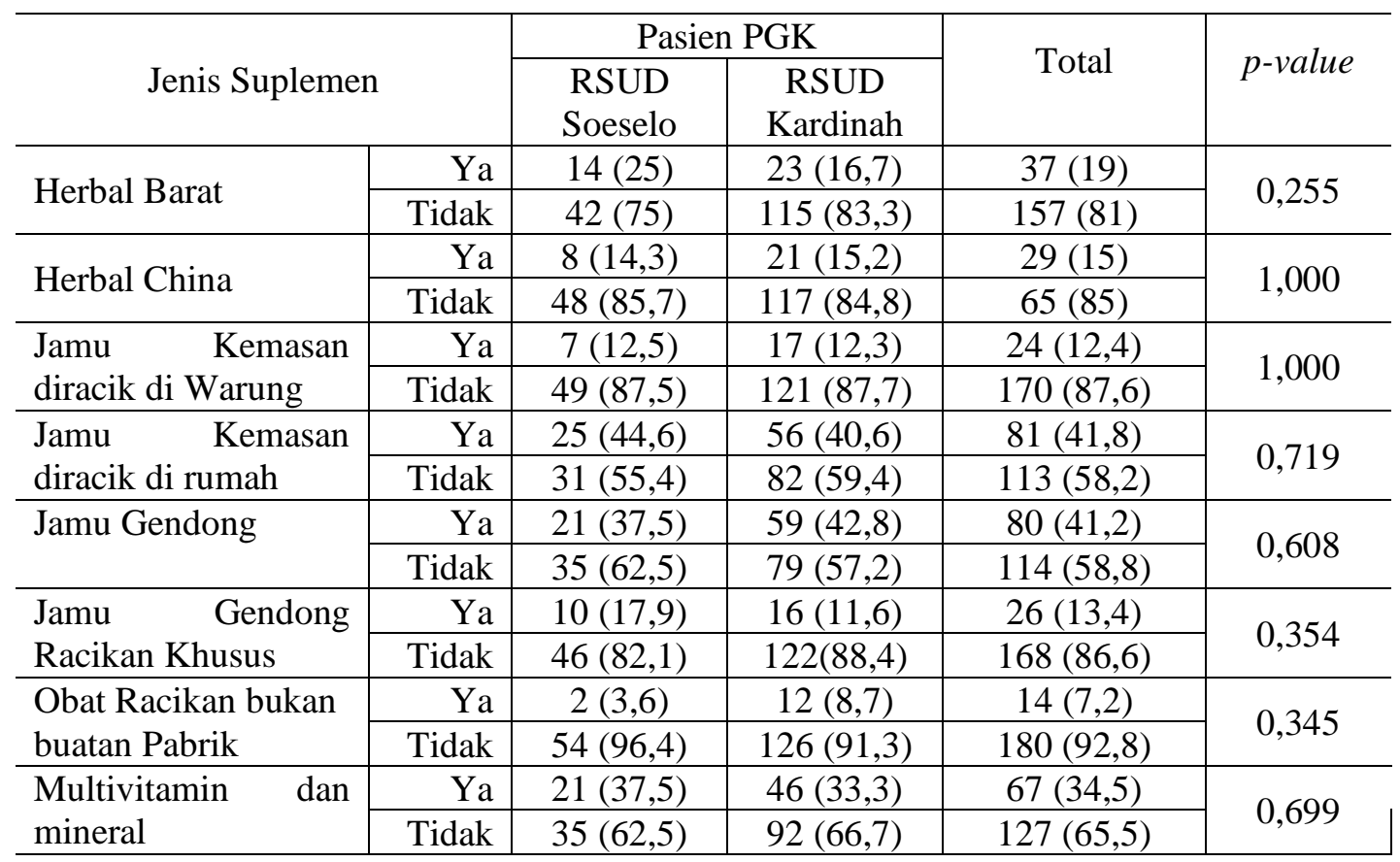

Perilaku penggunaan obat atau suplemen kesehatan sebelum pasien terdiagnosa penyakit ginjal kronis yang menjalani pengobatan di RSUD Kardinah Kota Tegal dan RSUD Soeselo Kabupaten Tegal didapat hasil bahwa penggunaan suplemen yang paling banyak jamu kemasan (diracik di rumah) sebesar 22,6\% kemudian diikuti dengan jamu gendong yaitu sebesar $22,4 \%$ dan sebanyak $18,7 \%$ menggunakan multivitamin dan mineral. Perilaku penggunaan jamu kemasan, jamu gendong serta multivitamin dan mineral ternyata didominasi oleh pasien ginjal kronis dengan tingkat pendidikan sedang (smp dan sma). Untuk proporsi perilaku penggunaan obat atau suplemen kesehatan untuk menjaga kesehatan dan

\section{Simpulan}

Pada penelitian ini didapatkan profil riwayat penyakit yang diderita pasien penyakit ginjal kronis yaitu di dominasi penyakit hipertensi dan diabetes dengan jenis kelamin laki-laki dengan proporsi yang sebanding di kedua rumah sakit. Untuk profil pengobatan hipertensi pada RSUD Soeselo dan RSUD Kardinah didapat hasil yang berbeda dimana untuk penggunaan obat hipertensi di RSUD Soeselo paling banyak menggunakan CCB sedangkan untuk RSUD Kardinah paling banyak menggunakan diuretik. Sedangkan stamina yaitu jamu kemasan, jamu gendong serta multivitamin dan mineral ternyata didominasi pasien ginjal kronis yang menjalani perawatan di RSUD Soeselo yang proporsinya paling banyak daripada di RSUD Kardinah.

Berdasarkan penelitian SUSENAS 2007 (National Socio-Economic Survey) bahwa penduduk indonesia yang mengeluh sakit dalam kurun waktu satu bulan sebelum dilakukan survei adalah 30,9\% dimana dari persentase yang mengeluh sakit sebesar $65.01 \%$ melakukan pengobat sendiri menggunakan obat dan obat tradisional sebagai pilihan terapinya. Penggunaan obat dan obat tradisional dalam upaya pengobatan sendiri terus meningkat dari $15,2 \%$ menjadi $38,3 \% .^{14}$

penggunaan obat diabetes oral di RSUD Soeselo dan RSUD Kardinah didominasi golongan sulfonilurea, sedangkan untuk penggunaan insulin hanya pada responden yang di RSUD Kardinah saja.

Pada perilaku penggunaan obat nyeri dan suplemen obat sebelum pasien terdiagnosa penyakit ginjal kronis di dapatkan hasil obat pereda sakit $(42,6 \%)$, obat paten yang dibeli sendiri $(32,2 \%)$ serta obat china $(16,1 \%)$ sedangkan untuk jenis obat atau suplemen obat yang paling banyak yaitu jamu kemasan yang diracik dirumah $(22,6 \%)$, jamu gendong $(22,4 \%)$, multivitamin dan mineral $(18,7 \%)$. 
Perilaku penggunaan obat nyeri didapat perbedaan yang signifikan yaitu pada penggunaan jamu kemasan di racik dirumah dan jamu gendong dimana proporsi penggunaan di RSUD Kardinah jauh lebih tinggi daripada di RSUD Soesilo dimana nilai $\mathrm{p}$-value $(\mathrm{p}<0,05)$ sedangkan pada penggunaan obat atau suplemen kesehatan tidak ditemukan perbedaan secara signifikan $(p>0,05)$ untuk perilaku penggunaan suplemen kesehatan untuk menjaga stamina dan kesehatan di kedua rumah sakit.

\section{PUSTAKA}

[1] Desita A. Saragih. Hubungan Dukungan Keluarga dengan Kualitas Hidup Pasien Gagal Ginjal Kronis yang Menjalani Terapi Hemodialisa di RSUP Haji Adam Malik Medan (Skripsi). Universitas Sumatra Utara [Internet]. 2010; Available from: http://repository.usu.ac.id/handle/123456 789/20218

[2] Bansal M and Jamil S., 2018. Micellar Chisholm-Burns MA, Wells BG, Schwinghammer TL, Malone PM, Kolesar JM, Rotschaefer JC, et al. Pharmacotherapy principles \& practice. The McGraw-Hill Companies; 2008.

[3] Rachmadi D. ( Chronic Kidney Disease ) Departemen Ilmu Kesehatan Anak Fakultas Kedokteran Universitas Padjadjaran Rumah Sakit Hasan Sadikin Bandung. 2010

[4] Chan K. Some aspects of toxic contaminants in herbal medicines. Chemosphere. 2003;52(9):1361-71

[5] Wirayukti B. Profil Pengobatan dan Evaluasi Dosis Pemberian Obat pada Pasien Gagal Ginjal Kronis Periode Januari-Desember Tahun 2006. Universitas Muhammadiyah Surakarta; 2006.

[6] Dale P. Sandler P., Joanna et al. Analgesic Use and Chronic Renal Disease. N Engl J Med [Internet]. 2010; 320. Availablefrom: http://www.nejm.org/doi/pdf/10.1056 / NEJM198905113201903.

[7] Hidayati. Evaluasi penggunaan terapi anemia pada pasien askes dengan gagal ginjal kronik yang menjalani hemodialisis rutin di RS PKU Muhammadiyah Yogyakarta (Tesis). Yogyakarta: Fakultas Farmasi Universitas Gadjah Mada; 2011.

[8] Muharni SI. Pola hidup penderita gagal ginjal kronik sebelum menjalani terapi haemodialisa di BPK RSU Langsa (SKRIPSI). Sumatera Utara: Fakultas Keperawatan Universitas Sumatera Utara; 2009, h 25.

[9] Fitriani. Evaluasi Penggunaan Terapi Antihipertensi Terhadap Tekanan Darah Pra-Dialisis Pada Pasien Rawat Jalan Dengan End Stage Renal Disease (ESRD) Yang Menjalani Hemodialisis Rutin Di RS PKU Muhammadiyah Yogyakarta (Tesis). Yogyakarta: Fakultas Farmasi Universitas Gadjah Mada; 2011.

[10] Arsono, S. Diabetes Melitus Sebagai Faktor Risiko Kejadian Gagal Ginjal Terminal; Studi Kasus Pada Pasien RSUD Prof. DR. Margono Soekarjo Purwokerto (Tesis). Semarang: Program Pasca Sarjana Epidemiologi Universitas Diponegoro Semarang; 2005.

[11] Bagnis C I, MD, PhD, Deray G, MD, Baumelou A, MD, Quintrec M L, MD, and Vanherweghem J L, MD. Herbs and the Kidney. American Journal of Kidney Diseases. Vol 44, No 1, Juli 2004.

[12] Puspita P, Hidayati T. Hubungan Antara Keteraturan Konsumsi NSAID dan Kortikosteroid Terhadap Kejadian Gagal Ginjal Kronik Terminal di RSU PKU Muhammadiyah Yogyakarta. [SKRIPSI]. Yogyakarta: Fakultas Kedokteran dan Ilmu Kesehatan Universitas Muhamadiyah Yogyakarta. 2011.

[13] Horl, W.H., 2010, Nonsteroidal Antiinflammatory Drugs and the Kidney, Pharmaceuticals, 3, 2291-2321.

[14] Supardi Y, Herman MJ, Yuniar Y. Penggunaan Jamu Buatan Sendiri Di Indonesia (Analisis Data Riset Kesehatan Dasar Tahun 2010). Surabaya. Bulletin of Health System Research. Vol 14, No 4, Oktober 2011. 